\title{
Interactions of microorganisms with rare earth ions and their utilization for separation and environmental technology
}

\author{
Hiroshi Moriwaki*and Hiroki Yamamoto \\ Shinshu University, Faculty of Textile Science and Technology, Division of Applied Biology, 3-15-1, \\ Tokida, Ueda 386-8567, Japan \\ * To whom correspondence should be addressed. \\ E-mail: moriwaki@shinshu-u.ac.jp
}




\begin{abstract}
In recent years, rare earth elements (REEs) have been widely used in various modern technological devices, and the global demand for REE has been increasing. The increased demand for REEs has led to environmental exposure or water pollution from rare earth metal mines and various commercial products. Therefore, the development of a safe technology for the separation and adsorption of REEs is very important from the perspective of green chemistry and environmental pollution. In this review, the application and mechanisms of microorganisms for the removal and extraction of REEs from aqueous solutions are described. In addition, the advantages in using microorganisms for REE adsorption and future studies on this topic are discussed.
\end{abstract}

Keywords rare earth elements · adsorption · microorganisms $\cdot$ mechanism· teichoic acid 


\section{Introduction}

The rare earth elements (REEs) are a group of metals comprising a set of 15 or 16 elements in the periodic table, specifically the 14 lanthanides ( $\mathrm{Pm}$, whose isotopes are radioactive with short half-lives, is generally excluded.), yttrium, and sometimes scandium. REEs are widely used in various technological devices, including superconductors ( $\mathrm{Y}, \mathrm{La}$, and $\mathrm{Lu}$ ), magnets $(\mathrm{Ce}, \mathrm{Nd}, \mathrm{Sm}, \mathrm{Gd}$, $\mathrm{Tb}$, and $\mathrm{Dy}$ ), fluorescent materials ( $\mathrm{Sc}, \mathrm{Y}, \mathrm{Eu}, \mathrm{Tb}$, and $\mathrm{Tm}$ ), and catalysts (Y, La, and $\mathrm{Ce}$ ) (Andrianov et al. 2011; Molander and Romero 2002). The demand for REEs is rapidly increasing worldwide.

China has played a dominant role in REE mining production since 1990 (Du et al. 2011). Recently, high concentrations of REEs have been found in the deep-sea mud at numerous sites throughout the eastern South and central North Pacific (Kato et al. 2011). However, the REE resources are not exploited commercially at the present time because of the technical difficulty and high cost of mining. The importance of REEs as a resource has been tremendously growing, and as a result their monetary value has been increasing.

Techniques for the separation and purification of REEs have gained in importance with the increasing demand for REEs. Various kinds of phosphates or functionalized polymers have been widely used for these purposes (Chen et al. 2012; Sun et al. 2012; Buchmeiser et al. 1998; Zahir and Masuda 1997). However, most of these reagents are expensive and may be toxic themselves. Under these circumstances, it is very important to develop low-cost and environmentally friendly procedures for the extraction of rare earth ions from water. It is well known that REEs exhibit hepatotoxic and neurotoxic effects (Pałasz and Czekaj 2000; Basu et al. 1982). However, up to now, carcinogenicity of REEs in animals has not been reported (Hirano et al. 1996). More and more REEs diffuse into the environment because they are being rapidly exploited and widely used in modern industry and daily life. In fact, in one report, high levels of rare earth metals were detected in hair from the scalp of children living in a rare earth metals mining area in China (Tong et al. 2005). It is 
of great concern that the spreading of REEs has adverse effects on living organisms. Therefore, it is very important to develop a safe adsorbent and a procedure for its use in removing REEs from the aqueous environment.

It is beneficial to use bioresource materials as adsorbents for environmental pollutants, because they are economic and eco-friendly (Babel and Kurniawan 2003; Sud et al. 2008). Recently, various bioresource materials have been used as adsorbents for pollutants such as oil, pesticides, and metal ions (Moriwaki et al. 2009; Senthilkumaar et al. 2010; Ghimire et al. 2003; Demirbas 2008). In particular, applications of microorganisms for the removal of heavy metal ions from aqueous environments have received much attention, and intensive studies have been performed on a variety of bacteria to improve these procedures (Kuroda and Ueda 2010; Wu et al. 2012).

The processes for the removal of heavy metal ions by using microorganisms may be divided into four categories, as shown in Fig. 1. An efficient and widely applied technique involves the adsorption of metal ions on the surface of microbial cells. Another well-known technique involves the adsorption of metal ions by extracellular biopolymers, such as polyglutamic acid and polysaccharide. A third technique of metal ion removal from solution involves their absorption into microbial cells (Klaus-Joerger et al. 2001) and a forth technique involves adsorption by bio-minerals such as manganese oxide (Tani et al. 2004).

Adsorption of metal ions by the microbial cell surface is well understood. There are various advantages of using microbial cell surfaces as adsorbents, which include high efficiency of adsorption of dissolved metals because microbial cells have a high surface area per unit weight and metal adsorption by them has a relatively small impact on the environment (Wu et al. 2012).

Several studies dealing with REE adsorption by bacterial cells were published recently (Merroun et al. 2003; Takahashi et al. 2005; Ozaki et al. 2006). In particular, interactions between the bacterial cell wall and REEs were studied to gain insights into the mechanism of REE adsorption and to shed 
light on their potential utility of bacterial cell walls as adsorbents for REEs. Understanding interactions between the bacterial cell wall and REEs provides useful information about the environmental behavior and geological distribution of REEs.

Andrès et al. (2003) published a review on the removal of REEs by microbial bio-sorption. The interaction of the surface of a bacterium with REEs at the molecular level has not been studied until recently, however, the selective accumulation of REEs by bacteria has been the focus of several recent studies. In this review, we summarize the results of REE adsorption onto bacterial cells from studies conducted in the last decade. In particular, we describe in detail the mechanism of the interaction between the microbial cell wall and REEs at the molecular level.

REE adsorption by microorganisms

Table 1 summarizes some of the major published REE sorption experiments on bacteria. REE adsorption by various bacterial strains was examined. In particular, many researchers studied the adsorption onto the cell wall of gram-positive bacteria such as Bacillus subtilis, and gram-negative bacteria such as Escherichia coli. For example, the adsorption behaviors of Eu(III) on 3 kinds of gram-negative bacteria were compared, and the coordination environment of $\mathrm{Eu}(\mathrm{III})$ on the bacteria were found to be different (Ozaki et al. 2005). Moreover, the adsorption behavior of Eu(III) on Halobacterium salinarum was also investigated (Ozaki et al. 2002a). The authors concluded that the coordination states of $\mathrm{Eu}(\mathrm{III})$ adsorbed on the $B$. subtilis and $H$. salinarum had different characteristics.

Various microbial cells can produce extracellular polymeric substances (EPS), which lead to floc formation due to the agglomeration of bacteria (Sponza 2002). EPS provide an extensive surface area per unit volume for adsorption of heavy metal ions, such as $\mathrm{Pb}$ (Rudd et al. 1984). This suggests 
that the EPS could protect the bacterium in its habitat because these substances facilitate heavy metal fixation surrounding the cell rather than inside the cells (Merroun et al. 1998). Merroun et al. (2003) reported that Myxococcus xanthus, a soil bacterium of the myxobacteria group, could accumulate 0.6 mmol of La / $\mathrm{g}$ of wet biomass and/or $0.99 \mathrm{mmol} / \mathrm{g}$ of dry biomass, and a substantial amount of La was fixed in the EPS and in the cell wall.

Bacterial oxidation results in the precipitation of biogenic minerals such as silica, iron oxides (Fortin and Langley 2005), and manganese oxide (Tani et al. 2003). The adsorption of REEs on biogenic Mn oxide produced by Acremonium sp. strain KR21-2 has been reported (Tanaka et al. 2010).

In addition, it was reported that organic molecules, such as siderophore, iminoacetic acid, nitrotriacetic acid, and ethylenediamine tetraacetic acid affect the sorption behavior of REEs on cell surfaces by forming complexes with REEs (Yoshida et al. 2004; Takahashi et al. 2005). These results indicate that the complexation of REEs with organic molecules released from bacterial cells affect the behavior of REEs in the environment.

Selective accumulation of RREs using microorganisms

In order to separate REEs by use bacteria, the capacity of the bacteria to achieve separation of REEs and of other metals has to be assessed.

Several studies have reported the preferential adsorption of REEs over that of other metals. For example, the adsorptive removal of $\mathrm{Tm}$ (III) from a Fe(II) and Tm(III) binary solution (20 mL, 20 $\mu \mathrm{g} / \mathrm{mL}, \mathrm{pH} 3$ ) by the cell walls of B. subtilis was studied (Moriwaki et al. 2011). The percentage of Tm(III) removed (89\%) from the solution was higher than the percentage of $\mathrm{Fe}(\mathrm{II})$ removed (5.3\%). This finding indicates that the cell wall of the B. subtilis strain can selectively accumulate REEs 
from a solution containing Fe(II). The unique properties of REEs include their strong Lewis acidity and their affinity for heteroatoms such as oxygen. Rare earth ions are known to interact with phosphate groups. Their adsorption onto the oxygen atom of the phosphate group of bacterial cell walls is more powerful than that of Fe(II). This explains the selective adsorption of rare earth ions onto the cell walls. It has also been reported that the relative degree of the metal accumulation by Arthrobacter nicotianae cells was $\mathrm{Sm}^{3+}>>\mathrm{Cu}^{2+}, \mathrm{Mn}^{2+}, \mathrm{Co}^{2+}, \mathrm{Ni}^{2+}, \mathrm{Zn}^{2+}$, and $\mathrm{Cd}^{2+}$, indicating that $A$. nicotianae can accumulate $\mathrm{Sm}^{3+}$ more than the other type of metal ions (Tsuruta 2006).

It is very difficult to separate REEs from each other because their physicochemical properties, such as ionic radii, valence, and magnetic properties, are very similar (Miyawaki and Nakai 1993). At present, the separation of REEs from each other is predominantly achieved by solvent extraction procedures (Fontana and Pierelli 2009), but the methods generically require large amounts of organic solvent. Therefore, adsorbents that exhibit selectivity for a specific REE need to be developed. Bacteria that adsorb REEs selectively may satisfy such a need.

The distribution coefficient $\mathrm{K}_{\mathrm{d}}$ has been frequently used to assess the selectivity of adsorbents for different REEs. The distribution coefficient $K_{d}$ between a liquid and solid phase for [REE], expressed in $\mathrm{L} / \mathrm{g}$, is defined by the following equation:

$\mathrm{K}_{\mathrm{d}}=\left([\mathrm{REE}]_{\text {init }}-[\mathrm{REE}]_{\mathrm{dis}}\right) / c[\mathrm{REE}]_{\mathrm{dis}}$

where $[R E E]_{\text {dis }}$ is the concentration of REEs in the aqueous phase, and $[R E E]_{\text {init }}$ is the initial concentration of each dissolved REE. The variable $c(\mathrm{~g} / \mathrm{L})$ is the ratio of the solid to the solution.

The REE distribution patterns for the adsorption of the REE onto bacterial cells such as $B$. subtilis and E. coli have been studied (Takahashi et al. 2005). The $\mathrm{K}_{\mathrm{d}}$ of the REE between the bacterial cell surface and the solution showed a pattern with a prominent enrichment of heavy REEs 
such as Tm, $\mathrm{Yb}$, and Lu, and included a maximum enrichment around $\mathrm{Sm}$ and Eu. Enrichment was also observed around Pr and was accompanied by a decline for Nd. A similar $\mathrm{K}_{\mathrm{d}}$ pattern for REE adsorption was observed for other bacteria, Alcaligenes faecalis, Shewanella putrefaciens, and Pseudomonas fluorescens (Takahashi et al. 2007). Tanaka et al. (2010) reported the sorption of REEs on biogenic Mn oxide produced by Acremonium sp. strain KR21-2, and a large positive Ce anomaly in the distribution coefficient of the REE between the adsorbent and solution. They concluded that the Ce adsorption was due to Ce oxidation by biogenic Mn oxide.

Selectivity in REE adsorption by bacteria affects the geological and environmental distribution of REEs. In fact, Takahashi et al. (2007) reported that the REE patterns from biofilms formed in a groundwater discharge area in the Budo pond in Hiroshima were similar to the pattern obtained from the culture-based experiments.

Mechanism of REE adsorption on cell wall of microorganisms

In order to understand how bacteria are able to adsorb REEs selectively, the mechanism by which they adsorb REEs needs to be understood. Many researchers have investigated REE-binding sites on microbial cell walls. Several experimental approaches have been used to understand microbial REEbinding sites.

Time-resolved laser-induced fluorescence spectroscopy (TRLFS) is a very sensitive, selective, and fast method for the analysis of fluorescent lanthanides that has been extensively used to determine the coordination structure of metals adsorbed by microorganisms (Texier et al. 2000). A simultaneous determination of emission wavelength and fluorescence lifetime provides structural information about fluorescing ions. The $\mathrm{Eu}(\mathrm{III})$ ion, which exhibits a strong fluorescence, is particularly suitable for such investigations. The fluorescence lifetime of $\mathrm{Eu}(\mathrm{III})$ is related to the 
number of water molecules in the primary coordination sphere $\left(N_{\mathrm{H} 2 \mathrm{O}}\right)$. The determination of $N_{\mathrm{H} 2 \mathrm{O}}$ for $\mathrm{Eu}(\mathrm{III})$ in a complex is useful to predict the coordination structure in the inner-sphere. The relative intensity of fluorescence spectra $\left(R_{\mathrm{E} / \mathrm{M}}\right)$ serves as a good indicator for examining the symmetry around $\mathrm{Eu}(\mathrm{III})$, which is well correlated with the degree of interaction including both the inner- and outer- spheres (Ozaki et al. 2002b). The coordination states of Eu(III) adsorbed on the B. subtilis and $H$. salinarum cells were investigated by TRLFS (Ozaki T et al. 2002a). The result indicated that $H$. salinarum exhibited more outer-sphere interaction with Eu(III) than B. subtilis. Furthermore, TRLFS confirmed that $\mathrm{Eu}(\mathrm{III})$ complexed with both carboxylic and phosphate groups on the cell wall of $B$. subtilis (Markai et al. 2003).

Extended X-ray absorption fine structure (EXAFS), resulting from the interference of the photoelectrons scattered by the surrounding atoms, provides information about the local structure. Several researchers applied the technique to identify the REE-binding sites on the bacterial cell surfaces. The coordination number between the REE and carboxylic or phosphate group, REE-O distance, and the influence of water molecules on the interaction between the REE and phosphate can be estimated using EXAFS.

Using EXAFS measurement, Ngwenya et al. (2009) reported coordination of lanthanide with gram-negative cells. Their findings indicate a predominance of phosphate binding of REEs at low $\mathrm{pH}$ and an increase of REE-carboxylate binding as the $\mathrm{pH}$ increased. On a stoichiometric basis, inner-sphere complexation involving REEs was the most likely reaction that led to proton exchange.

The REE binding sites at the cell surface of B. subtilis, which are implicated in the enrichment of heavy REEs on the basis of distribution coefficient studies, were studied using EXAFS (Takahashi et al. 2010). The EXAFs data showed that the heavy REEs form complexes with multiple phosphate sites with a large coordination number, whereas at $\mathrm{pH} 3.5$, REEs of light and middle REEs form complexes at the phosphate site that exhibit a lower coordination number. On the basis of these 
results, the structure and number of phosphate sites of bacteria determine the partitioning of REE between bacteria and the aqueous phase.

The results of TRLFS and EXAFS experiments suggest that the REE-binding sites of bacteria are phosphate and carboxyl groups present in the cell wall. Gram-negative bacteria contain phosphate groups at $\mathrm{N}$-acetylglucosamine phosphates, which are structural components of Lipid $\mathrm{A}$ in the outer membrane. Macroscopic analysis with X-ray absorption spectroscopic measurements and EXAFS suggested that the phosphate sites located on $\mathrm{N}$-acetylglucosamine phosphate are the binding site of REEs (Ngwenya et al. 2009).

On the other hand, the major structural compounds in the cell wall of gram-positive bacteria are teichoic acids and peptidoglycans (Neuhaus and Baddiley 2003; Schirner et al. 2009). Teichoic acids are bacterial polysaccharides that consist of glycerol phosphate or ribitol phosphate (Fig. 2a), and they are present in 2 distinct forms depending on whether they are linked to the head groups of membrane lipids (lipoteichoic acids) or to the peptidoglycan wall (wall teichoic acids) (Fig. 2b). In order to evaluate the distribution of lipoteichoic acid relative to the REE adsorption of $B$. subtilis cell wall, the REE adsorption of the freeze-dried cell powder of a wild type (WT powder) and lipoteichoic acid-defective strain ( $\Delta$ LTA powder) were compared (Moriwaki et al. 2012). It was found that the percentage removal of $\mathrm{La}, \mathrm{Eu}$, and Tm ions by using WT powder from water was greater than that by $\Delta$ LTA powder (Fig.3). This result indicates that lipoteichoic acid contributes to the adsorption of REEs by the cell wall of $B$. subtilis.

\section{Conclusions and perspectives}

Various bacteria have been studied for their use as REE adsorbents. Such microbes have excellent capacity and selectivity for REE adsorption. The REE partitioning between the bacterial cell wall and the aqueous solution frequently exhibits anomalous enrichment in the heavy REE part. 
Furthermore, several studies have shown that microorganisms that were used as adsorbent materials selectively adsorbed REEs from mixtures of REE and other metal ions. Using TRLFS, EXAFS, and genetically modified strains, the REE adsorption sites were studied in considerable detail, and the adsorption mechanisms were elucidated. The binding sites of the bacterial cell wall are phosphate and carboxyl groups, and it is strongly suggested that the interaction between these sites and REEs determine the selectivity of the microbial materials.

However, many problems remain when bacteria are used to remove or collect REEs from the environment. At this stage, it is difficult to use bacteria as REE adsorbents because of the high costs. Desorption of REEs from microbial adsorbents needs to be developed for recovery of REEs as a resource. Desorption of REEs from soil has been actively studied (Shan et al. 2002). Establishing an elution method by exploiting these techniques would make it possible to reuse the microbial adsorbent.

B. subtilis 168 is the gram-positive model organism and its genome databases are quite substantial. In addition, the biosynthetic pathways of both wall- and lipo-teichoic acids are well understood (Lazarevic et al. 2002; Schirner et al. 2009; Wörmann et al. 2011; Reichmann et al. 2011). Gene inactivation procedure is fully established in this organism. Therefore, in order to improve REE adsorption, approaches using genetic modification would be possible. For example, the freeze-dried cell powder of the lipoteichoic acid-defective strain (LTA powder) has an advantage for REE removal compared with the wild-type strain. The $\triangle$ LTA powder readily coagulated and sedimented in the presence of REEs. On the other hand, such coagulation and sedimentation did not occur with the WT powder and rare earth ion aqueous solution under the same conditions (Moriwaki et al. 2012). The length of time required for the filtration of the test solution $(20 \mathrm{~mL})$ by using $5 \mathrm{~A}$ filtration paper were 105 and $43 \mathrm{~s}$ for the WT powder and $\triangle \mathrm{LTA}$ powder, respectively. This result suggests that $\triangle$ LTA powder is useful for the extraction of rare earth ions from water. 
It will be possible to construct the mutant strains, which have a high selectivity or unique adsorption behavior and to use them in environmental applications in the future, when the mechanistic theory of the REE adsorption on the microbial cells is advanced further. Additional work is required to develop a better application for bacteria as REE adsorbents for separation and in the environment.

\section{Acknowledgments}

A part of this work was supported by Grants-in-Aid for Scientific Research (C) (19580085 and 23580107) and grants from the Kurata Memorial Hitachi Science and Technology Foundation, the Nagase Science and Technology Foundation, the Research Foundation for the Electrotechnology of Chubu, and Institute for Fermentation, Osaka to H.Y.

\section{References}

Anderson CR, Pederson K (2003) In situ growth of Gallionella biofilms and partitioning of lanthanides and actinides between biological material and ferric oxyhydroxides. Geobiol. 1: 169-178.

Andres Y, Texier AC, Cloirec PL (2003) Rare earth elements removal by microbial biosorption : A review. Environ. Technol. 24: 1367-1375

Andrianov AV, Savel'eva OA, Bauer E, Staunton JB (2011) Squeezing the crystalline lattice of the heavy rare earth metals to change their magnetic order: Experiment and ab initio theory. Phys. Rev. B. 84: 132401

Basu A, Chakrabarty K, Chatterjee GC (1982) Neurotoxicity of lanthanum chloride in newborn chicks. Toxicol. Lett. 14: 21-25

Babel S, Kurniawan TA (2003) Low-cost adsorbents for heavy metals uptake from contaminated 
water: a review. J. Hazard. Mater. 97: 219-243

Buchmeiser MR, Tessadri R, Seebar G, Bonn GK (1998) Selective extraction of rare earth elements from rocks using a high-capacity cis-1,4-butanedioic acid functionalized resin. Anal. Chem. 70: $2130-2136$

Chen Y, Zhu B, Wu D, Wang Q, Yang Y, Ye W, Guo J (2012) Eu(III) adsorption using di(2-thylhexly)phosphoric acid-immobilized magnetic GMZ bentonite. Chem. Eng. J. 181-182: 387-396

Demirbas A (2008) Heavy metal adsorption onto agro-based waste materials: A review. J. Hazard. Mater. 157: 220-229

Du X, Graedel TE (2011) Global in-use-stocks of the rare earth elements: A first estimate. Environ. Sci. Technol. 45: 4096-4101

Fontana D, Pietrelli L (2009) Separation of middle rare earths by solvent extraction using 2-ethylhexylphosphonic acid mono-3-ethylhexyl ester as an extractant. J. Rare Earths 27: $830-833$

Fortin D, Langley S (2005) Formation and occurrence of biogenic iron-rich minerals. Earth-Sci. Re. 72: $1-19$

Ghimire KN, Inoue K, Yamaguchi H, Makino K, Miyajima T (2003) Adsorptive separation of arsenate and arsenite anions from aqueous medium by using orange waste. Water Res. 37: $4945-4953$

Haferburg G, Merten D, Buchel G, Kothe E (2007) Biosorption of metal and salt tolerant microbial isolates from a former uranium mining area. Their impact on changes in rare earth element patterns in acid mine drainage. J. Basic Microbiol. 47: 474-484.

Hirano S, Suzuki KT (1996) Exposure, metabolism, and toxicity of rare earths and related compounds. Environ. Health Perspect. 104 (Suppl 1): 85-95 
Kato Y, Fujinaga K, Nakamura K, Takaya Y, Kitamura K, Ohta J, Toda R, Nakashima T, Iwamori H (2011) Deep-sea mud in the Pacific Ocean as a potential resource for rare-earth elements. Nature Geosci. 4: 535-539

Klaus-Joerger T, Joerger R, Olsson E, Granqvist C-G (2001) Bacteria as workers in the living factory: metal-accumulating bacteria and their potential for materials science. Trends Biotechnol. 19: 15-20

Kuroda K, Ueda M (2010) Engineering of microorganisms towards recovery of rare metal ions. Appl. Microbiol. Biotechnol. 87: 53-60

Lazarevic V, Pooley HM, Mauël C, Karamata D (2002) Teichoic and teichuronic acids from Gram-positive bacteria. In: Biopolymers, Vol. 5, Polysaccharides I: Polysaccharides from Prokaryotes, Vandamme, E.J., DeBaets, S., and Steinbüchel, A. (Ed.), Weinheim: Wiley- VCH, pp. $465-492$.

Markai S, Andres Y, Montavon G, Grambow B (2003) Study of the interaction between europium(III) and Bacillus subtilis fixation sites, biosorption modeling and reversibility. J. Colloid Interf. Sci. 262: 351-361

Merroun ML, Ben Omar N, Gonzalez-Munoz MT, Arias JM (1998) Myxococcus xanthus biomass as biosorbent for lead. J. Appl. Microbiol. 84: 63-67.

Merroun ML, Chekroun KL, Arias JM, González-Munoz MT (2003) Lanthanum fixation by Myxococcus xanthus: cellular location and extracellular polysaccharide observation. Chemosphere 52: 113-120

Miyawaki R, Nakai I (1993) Crystal structures of rare earth minerals. In: Gshneidner K, Eying L (ed), Handbook of the physics and chemistry of rare earths. vol.16, Elsevier, pp.230-257

Molander GA, Romero JAC (2002) Lanthanocene catalysts in selective organic synthesis. Chem. Rev. 102: 2161-2185 
Moriwaki H, Kitajima S, Kurashima M, Hagiwara A, Haraguchi K, Shirai K, Kanekatsu R, Kiguchi K (2009) Utilization of silkworm cocoon waste as a sorbent for the removal of oil from water. J. Hazard. Mater. 165: 266-270

Moriwaki H, Koide R, Yoshikawa R, Warabino Y, Yamamoto H (2012) Adsorption of rare earth ions onto the cell walls of wild type and lipoteichoic acid-defective strains of Bacillus subtilis, Appl. Microbiol. Biotech. doi: 10.1007/s00253-012-4200-3

Neuhaus FC, Baddiley J (2003) A continuum of anionic charge: structures and functions of D-alanyl-teichoic acids in gram-positive bacteria. Microbiol. Mol. Biol. Rev. 67: 686

Ngwenya BT, Mosselmans JFW, Megennis M, Atkinson KD (2009) Macroscopic and spectroscopic analysis of lanthanide adsorption to bacterial cells. Geochim. Cosmochim. Acta 67: 3299-3312

Ozaki T, Gillow JB, Francis AJ, Kimura T, Ohnuki T, Yoshida Z (2002a) Association of Eu(III) and Cm(III) with Bacillus subtilis and Halobacterium salinarum. J. Nucl. Sci. Technol. 3 (Suppl.): 950-953

Ozaki T, Arisaka M, Kimura T, Francis AJ (2002b) Empirical method for prediction of the coordination environment of Eu(III) by time-resolved laser-induced fluorescence spectroscopy. Anal. Bioanal. Chem. 374: 1101-1104

Ozaki T, Kimura T, Ohnuki T, Francis AJ (2005) Associations of Eu(III) with gram-negative bacteria, Alcaligenes faecalis, Shewanella putrefaciens, and Paracoccus denitrificans. J. Nucl. Radiochem. Sci. 6: 73-76

Ozaki T, Suzuki Y, Nankawa T, Yoshida T, Ohnuki T, Kimura T, Francis AJ (2006) Interactions of rare earth elements with bacteria and organic ligands. J. Alloys Compd. 408-412: 1334-1338

Pałasz A, Czekaj P (2000) Toxicological and cytophysiological aspects of lanthanides action. Acta Biochim. Polonica 47: 1107-1114

Reichmann NT, Gründling A (2011) Location, synthesis and function of glycolipids and 
polyglycerolphosphate lipoteichoic acid in Gram-positive bacteria of the phylum Firmicutes. FEBS Microbiol. Lett. 319, 97-105

Rudd T, Sterritt RM, Lester JN (1984) Formation and conditional stability constants of complexes formed between heavy metals and bacterial extracellular polymers. Water Res. 18: 379-384

Schirner K, Marles-Wright J, Lewis RJ, Errington J (2009) Distinct and essential morphogenic functions for wall- and lipoteichoic acids in Bacillus subtilis. EMBO J. 8: 830-842

Senthilkumaar S, Krishna SK, Kalaamani P, Subburamaan CV, G.-Subramaniam N (2010) Adsorption of organophosphorous pesticide from aqueous solution using "waste" Jute fiber carbon. Modern Appl. Sci. 4: 67-83

Shan X-q, Lian J, Wen B (2002) Effect of organic acids on adsorption and desorption of rare earth elements. Chemosphere 47: 701-710

Sponza DT (2002) Extracellular polymer substances physicochemical properties of flocs in steady and unsteady-state activated sludge systems. Process Biol. 37: 983-998.

Sud D, Mahajan G, Kaur MP (2008) Agricultural waste material as potential adsorbent for sequestering heavy metal ions from aqueous solutions - A review. Biores. Technol. 99: $6017-6027$

Sun X, Luo H, Dai S (2012) Solvent extraction of rare earth ions based on functionalized ionic liquids. Talanta 90: 132-137

Suzuki Y, Nankawa T, Yoshida T, Ozaki T, Ohnuki T, Francis AJ, Tsushima S, Enokida Y, Yamamoto I (2005) Sorption of Eu(III) on Pseudomonas fluorescens in the presence of citric acid. J. Nucl. Radiochem. Sci. 6: 91-93

Takahashi Y, Châtellier X, Hattori KH, Kato K, Fortin D (2005) Adsorption of rare earth elements onto bacteria cell walls and its implication for REE sorption onto natural microbial mats. Chem. Geol. 219: 53-67 
Takahasi Y, Hirata T, Shimizu H, Ozaki T, Fortin D (2007) A rare earth element signature of bacteria in natural waters? Chem. Geol. 244: 569-583

Takahashi Y, Yamamoto M, Yamamoto Y, Tanaka K (2010) EXAFS study on the cause of enrichment of heavy REE on bacterial cell surfaces. Geochim. Cosmochim. Acta 74: 5443-5462

Tanaka K, Tani Y, Takahashi Y, Tanimizu M, Suzuki Y, Kozai N, Ohnuki T (2010) A specific Ce oxidation process during sorption of rare earth elements on biogenic Mn oxide produced by Acremonium sp. Strain KR21-2. Geochim. Cosmochim. Acta 74: 5463-5477

Tani Y, Miyata N, Iwahori K, Soma M, Tokuda S, Seyama H, Theng BKG (2003) Biogeochemistry of manganese oxide coatings on pebble surfaces in the Kikukawa River system, Shizuoka, Japan. Appl. Geochem. 18: 1541-1554

Tani Y, Miyata N, Ohashi M, Ohnuki T, Seyama H, Iwahori K, Soma M (2004) Interaction of inorganic arsenic with biogenic manganese oxide produced by a Mn-oxidizing fungus, Strain KR21-2. Environ. Sci. Technol. 38: 6618-6624.

Texier AC, Andrès Y, Illemassen L, Cloirec PL (2000) Characterization of lanthanide ions binding sites in the cell wall of Pseudomonas aeruginosa. Environ. Sci. Technol. 34: 610-615

Tong SL, Zhu WZ, Gao ZH, Meng YX, Peng RL, Lu GC (2005) Distribution characteristics of rare earth elements in children's scalp hair from a rare earths mining area in southern china. J. Envoron. Sci. Health A 39: 2517-2532

Tsuruta T (2006) Selective accumulation of light or heavy rare earth elements using gram-positive bacteria. Colloids and Surfaces B: 117-122

Tsuruta T (2004) Adsorption of uranium from acidic solution by microbes and effect of thorium on uranium adsorption by Streptomyces levoris. J. Biosci. Bioeng. 97: 275-277

Wörmann ME, Corrigan RM, Simpson PJ, Matthews SJ, Gründling A (2011) Enzymatic activities and functional interdependencies of Bacillus subtilis lipoteichoic acid synthesis enzymes. Mol. 
Microbiol. 79, 566-583

Wu Y, Li T, Yang L (2012) Mechanisms of removing pollutants from aqueous solutions by microorganisms and their aggregates: A review. Bioresour. Technol. 107: 10-18

Yoshida T, Ozaki T, Ohnuki T, Francis AJ (2004) Adsorption of rare earth elements by $\gamma-\mathrm{Al}_{2} \mathrm{O}_{3}$ and Pseudomonas fluorescens cells in the presence of desferrioxamine B: implication of siderophores for the Ce anomaly. Chem. Geol. 212: 239-246

Zahir MdH, Masuda Y (1997) Extractive separation of trivalent lanthanide metals with a combination of Di(2-ethylhexyl)phosphoric acid and 1,10-phenanthroline. Talanta. 44: 365-371

\section{Figure captions}

Fig.1 Pattern diagrams for the interaction of heavy metal ions with bacteria.

Fig. 2 (a) Molecular structure of teichoic acid. (b) Schematic structure of the cell wall of gram-positive bacteria.

Fig.3 Removal (percentage) of La, Eu, and Tm ions from water using Bacillus subtilis powders (initial REE concentration: $20 \mu \mathrm{g} / \mathrm{mL} ; \mathrm{pH}=3$; adsorbent loading: $20 \mathrm{mg} / 20 \mathrm{~mL}$ ). 
Table 1 Publications dealing with REE adsorption by microorganism.

\begin{tabular}{|c|c|c|c|c|c|c|}
\hline Entry & Microorganisms & Mechanism & Metal ion & Results & Comments & Reference \\
\hline 1 & $\begin{array}{l}\text { Bacillus subtilis } \\
\text { Halobacterium } \\
\text { salinarum }\end{array}$ & $\begin{array}{l}\text { Adsorption } \\
\text { onto cell wall }\end{array}$ & $\mathrm{Eu}$ & $\begin{array}{l}\text { The coordination states of } \\
\text { Eu adsorbed on } H \text {. } \\
\text { salinarum was more } \\
\text { outer-spherical than Eu } \\
\text { adsorbed on } B \text {. subtilis. }\end{array}$ & $\begin{array}{l}\text { The coordination state of Eu } \\
\text { adsorbed on the micro-organisms } \\
\text { was studied by Time-resolved laser- } \\
\text { induced fluorescence spectroscopy } \\
\text { (TRLFS). }\end{array}$ & Ozaki et al. (2002a) \\
\hline 2 & Bacillus subtilis & $\begin{array}{l}\text { Adsorption } \\
\text { onto cell wall }\end{array}$ & $\mathrm{Eu}$ & $\begin{array}{l}\text { The Eu(III)/Bacillus } \\
\text { subtilis equilibrium was } \\
\text { reversible at } \mathrm{pH} 5 \text {. }\end{array}$ & $\begin{array}{l}\text { TRLFS was used to study lantanide } \\
\text { adsorption. }\end{array}$ & Markai et al. (2003) \\
\hline 3 & Myxococcus xanthus & $\begin{array}{l}\text { Adsorption to } \\
\text { extracellar } \\
\text { biopolymer } \\
\text { and cell wall }\end{array}$ & La & $\begin{array}{l}\text { La were adsorbed onto the } \\
\text { polysaccharide produced } \\
\text { by Myxococcus xanthus. }\end{array}$ & $\begin{array}{l}\text { La fixation on the extracellular } \\
\text { polymeric substances was confirmed } \\
\text { by TEM. }\end{array}$ & Merroun et al. (2003) \\
\hline 4 & Gallionella ferruginea & $\begin{array}{l}\text { Adsorption to } \\
\text { extracellar } \\
\text { mineral }\end{array}$ & $\begin{array}{l}14 \text { kinds } \\
\text { of REEs }\end{array}$ & $\begin{array}{l}\text { Bacteriogenic iron oxides } \\
\text { can accumulate REEs. }\end{array}$ & $\begin{array}{l}\text { Bacteriogenic Fe oxides can be } \\
\text { enriched in heavy REEs compared } \\
\text { to inorganic materials. }\end{array}$ & Anderson and Pedersen (2003) \\
\hline 5 & $\begin{array}{l}\text { Bacillus subtilis } \\
\text { Escherichia coli }\end{array}$ & $\begin{array}{l}\text { Adsorption } \\
\text { onto cell wall }\end{array}$ & $\begin{array}{l}15 \text { kinds } \\
\text { of REEs }\end{array}$ & $\begin{array}{l}\text { Tm, Yb, and Lu are } \\
\text { enriched on the cell wall of } \\
B \text {. subtilis and E. coli } \\
\text { compared to other REEs. }\end{array}$ & $\begin{array}{l}\text { The REE patterns of natural } \\
\text { microbial mat was similar to that } \\
\text { obtained in the laboratory } \\
\text { experiments using pure bacterial } \\
\text { strains. }\end{array}$ & Takahashi et al. (2005) \\
\hline 6 & $\begin{array}{l}\text { Alcaligenes faecalis } \\
\text { Schwanella putrefaciens } \\
\text { Paracoccus denitrificans }\end{array}$ & $\begin{array}{l}\text { Adsorption } \\
\text { onto cell wall }\end{array}$ & $\mathrm{Eu}$ & $\begin{array}{l}\text { TRLFS showed that the } \\
\text { coordination of Eu on the } \\
\text { bacteria differed, though } \\
\text { they are categorized as } \\
\text { Gram-negative bacteria. }\end{array}$ & $\begin{array}{l}\text { The associations of Eu with Gram- } \\
\text { negative bacteria by batch method } \\
\text { and TRLFS were studied. }\end{array}$ & Ozaki et al. (2005) \\
\hline 7 & $\begin{array}{l}\text { Pseudomonas } \\
\text { fluorescens }\end{array}$ & $\begin{array}{l}\text { Adsorption } \\
\text { onto cell wall }\end{array}$ & $\mathrm{Eu}$ & $\begin{array}{l}\text { Ciric acid reduced the } \\
\text { sorption of Eu on the } \\
\text { bacteria. }\end{array}$ & $\begin{array}{l}\text { I le rcc cumplexaluu vviu uryalıc } \\
\text { acid would be important for } \\
\text { estimating the environmental } \\
\text { hohsving of DFFc }\end{array}$ & Suzuki et al. (2005) \\
\hline 8 & $\begin{array}{l}\text { Arthobacter nicotianae } \\
\text { Streptomyces albus }\end{array}$ & $\begin{array}{l}\text { Adsorption } \\
\text { onto cell wall }\end{array}$ & $\begin{array}{l}15 \text { kinds } \\
\text { of REEs }\end{array}$ & $\begin{array}{l}\text { Both strain could efficiently } \\
\text { accumulate Sm and Eu. }\end{array}$ & $\begin{array}{l}\text { Sm was selectively accumulated by } \\
\text { A. nicotinae in the presence of } \mathrm{Cu} \text {, } \\
\mathrm{Mn}, \mathrm{Co}, \mathrm{Ni}, \mathrm{Zn} \text {, and } \mathrm{Cd} \text {. }\end{array}$ & Tsuruta (2006) \\
\hline 9 & $\begin{array}{l}\text { S. acidiscabies W-12 } \\
\text { M. Luteus W-20 } \\
\text { Bacillus sp. W-28 }\end{array}$ & $\begin{array}{l}\text { Adsorption } \\
\text { onto cell wall }\end{array}$ & $\begin{array}{l}14 \text { kinds } \\
\text { of REEs }\end{array}$ & $\begin{array}{l}\text { All investigated strains } \\
\text { displayed the sorption } \\
\text { characteristics for REEs. }\end{array}$ & $\begin{array}{l}\text { Three bacterial strain collected from } \\
\text { acid mine drainage was used for the } \\
\text { adsorbent of REEs. }\end{array}$ & Haferburg et al. (2007) \\
\hline 10 & $\begin{array}{l}\text { Bacillus subtilis } \\
\text { Escherichia coli } \\
\text { Alcaligene faecalis } \\
\text { Shewanella putrefaciens } \\
\text { Pseudomonas } \\
\text { fluorescens }\end{array}$ & $\begin{array}{l}\text { Adsorption } \\
\text { onto cell wall }\end{array}$ & $\begin{array}{l}14 \text { kinds } \\
\text { of REEs }\end{array}$ & $\begin{array}{l}\text { REE distributuion patterns } \\
\text { between bacteria and } \\
\text { water for five different } \\
\text { bacterial strains exhibit a } \\
\text { steep increase in the } \\
\text { heavy REE. }\end{array}$ & $\begin{array}{l}\text { The REE distribution patterns are } \\
\text { similar to those observed for biofilms } \\
\text { in the Budo Pond. }\end{array}$ & Takahashi et al. (2007) \\
\hline 11 & Pantoea agglomerans & $\begin{array}{l}\text { Adsorption } \\
\text { onto cell wall }\end{array}$ & $\begin{array}{l}\mathrm{La}, \mathrm{Nd} \\
\mathrm{Sm}, \mathrm{Gd} \\
\mathrm{Er}, \mathrm{Yb}\end{array}$ & $\begin{array}{l}\text { Extended X-ray absorption } \\
\text { fine structure spectrometry } \\
\text { (EXAFS) was applied to } \\
\text { compare the sorption of } \\
\text { REEs on bacteria. }\end{array}$ & $\begin{array}{l}\text { Surtace complexatıon modelıng was } \\
\text { consist with the light REEs } \\
\text { adsorbing to phosphate sites and } \\
\text { the middle and heavy REEs } \\
\text { adsorbing to carboxyl and phosphate } \\
\text { sites. }\end{array}$ & Ngwenya et al. (2009) \\
\hline 12 & Bacillus subtilis & $\begin{array}{l}\text { Adsorption } \\
\text { onto cell wall }\end{array}$ & $\begin{array}{l}15 \text { kinds } \\
\text { of REEs }\end{array}$ & $\begin{array}{l}\text { EXAFS data indicated that } \\
\text { heavy REEs formed } \\
\text { complexes with multiple } \\
\text { phosphate site at lower } \\
\text { REE-bacteria ratios. }\end{array}$ & $\begin{array}{l}\text { It was clear that the REE primary } \\
\text { bound to the phosphate site and } \\
\text { subsequently to the carboxylate site } \\
\text { on the bacterial cell surface. }\end{array}$ & Takahashi et al. (2010) \\
\hline 13 & $\begin{array}{l}\text { Acremonium sp. strain } \\
\text { KR21-2 }\end{array}$ & $\begin{array}{l}\text { Adsorption to } \\
\text { extracellar } \\
\text { biomineral }\end{array}$ & $\begin{array}{l}15 \text { kinds } \\
\text { of REEs }\end{array}$ & $\begin{array}{l}\text { The biogenic Mn oxide } \\
\text { produced by the bacteria } \\
\text { adsorbed REEs. }\end{array}$ & $\begin{array}{l}\text { Oxidation of } \mathrm{Ce}(\mathrm{III}) \text { to } \mathrm{Ce}(\mathrm{IV}) \text { by the } \\
\text { biogenic } \mathrm{Mn} \text { oxide was confirmed. }\end{array}$ & Tanaka et al. (2010) \\
\hline 14 & Bacillus subtilis & $\begin{array}{l}\text { Adsorption } \\
\text { onto cell wall }\end{array}$ & La, Eu, Tm & $\begin{array}{l}\text { RREs were efficiently } \\
\text { adsobed on microbial cell } \\
\text { wall. }\end{array}$ & $\begin{array}{l}\text { REE removal (\%) of lipoteichoic } \\
\text { acid-defective strain was lower than } \\
\text { that of wild type. }\end{array}$ & Moriwaki et al. (2012) \\
\hline
\end{tabular}


a) Surface adsorption

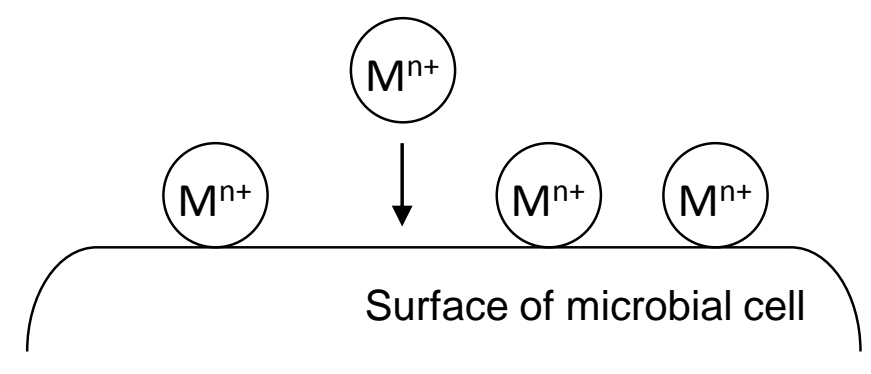

c) Biologic absorption

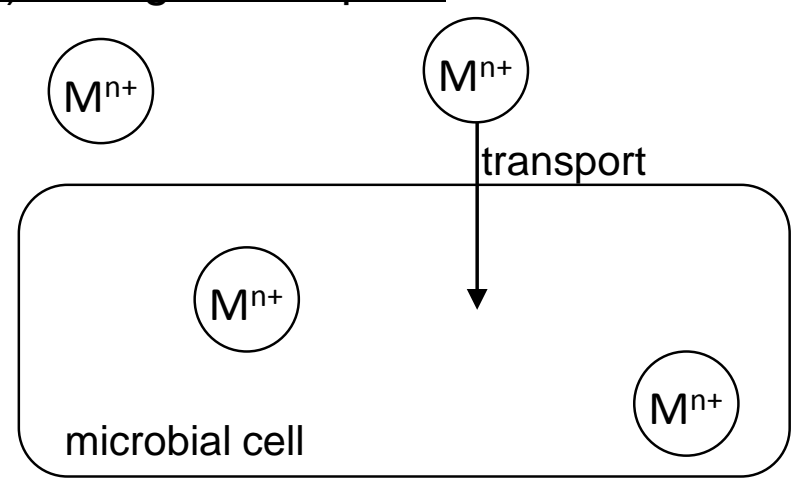

b) Adsorption on extracellular biopolymer

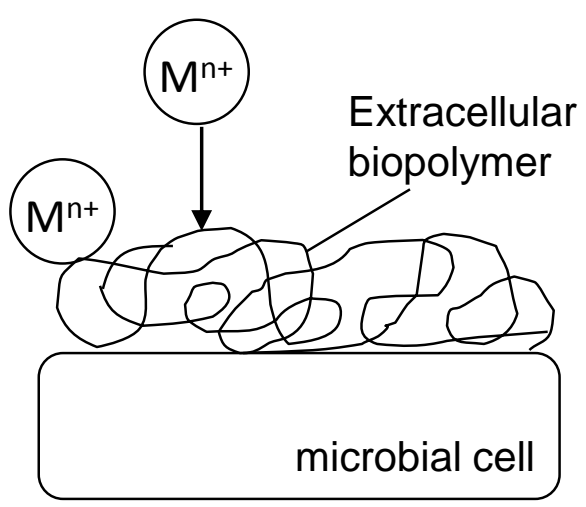

d) Adsorption on extracellular biomineral

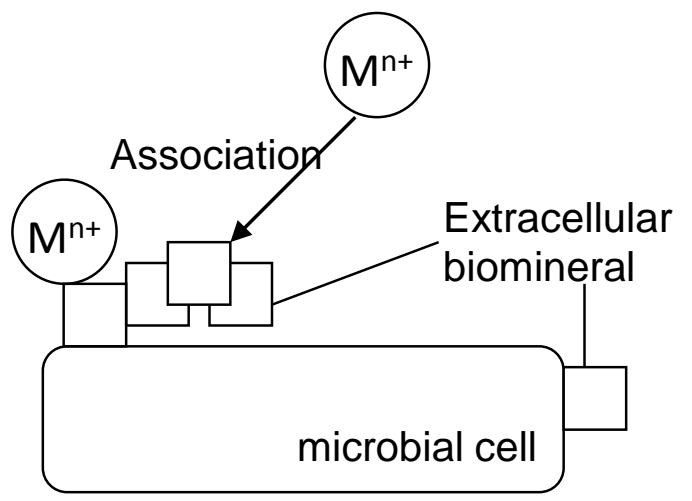

$\mathrm{M}^{\mathrm{n}}:$ metal ion

Fig.1 
a)<smiles>CCOP(=O)([O-])OC[C@@H](O)COP(=O)([O-])OC[C@H](O)COP(C)(=O)[O-]</smiles>

Teichoic acid

b)

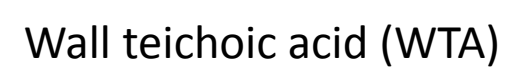




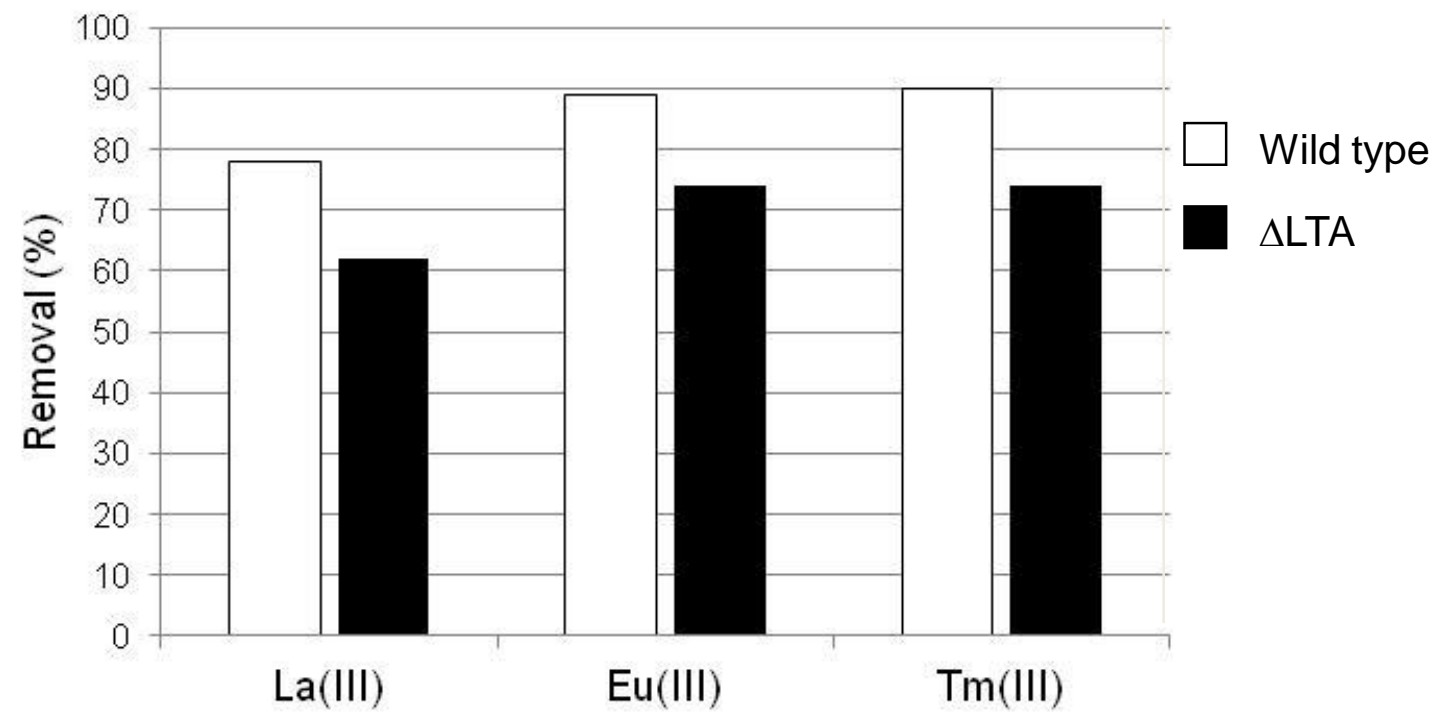

Fig. 3 